\title{
Akuntabilitas Pengelolaan Dana Desa Di Desa Umbulsari, Kabupaten Jember
}

\author{
Devi Ardiani $^{a}$, Dedy Wijaya Kusumab ${ }^{b}$ Nanda Widaninggar ${ }^{c}$ \\ ${ }^{a}$ Mahasiswa STIE MANDALA, deviardi1512@gmail.com \\ ${ }^{b}$ Dosen STIE MANDALA, dedy@stie-mandala.ac.id \\ ${ }^{c}$ Dosen STIE MANDALA, nanwiedha@stie-mandala.ac.id
}

\section{N F O A R T I K E L}

\section{Riwayat Artikel:}

24 Februari 2021

12 Maret 2021

12 April 2021

Keywords:

Accountability, Village Fund, Participation, Transparency

Kata Kunci:

Penerapan SOP, Sistem Penghargaan (Reward System), Pelatihan, Lingkungan Kerja dan Produktivitas Kerja

\begin{abstract}
A B S T R A C T
This research was conducted to describe and study the Village Fund Management Accountability System from the planning, implementation and accountability stages. This research uses a qualitative exploratory method through a case study approach. This study uses interviews which are carried out in depth to each informant. The results of this study indicate that the implementation stage of the Village Fund in Umbulsari Village has implemented the principles of participation and transparency. For the implementation stage of village funds, the principles of participation, transparency and accountability have been implemented. Meanwhile, at the accountability stage, village funds have implemented the principle of accountability.
\end{abstract}

\begin{abstract}
A B S T R A K
Penelitian ini dilaksanakan guna memaparkan maupun mengkaji Sistem Akuntabilitas Pengelolaan Dana Desa dari tahapan perencanaan, pelaksanaan serta pertanggungjawaban. Penelitian ini memakai metode kualitatif yang bersifat eksploratif melalui pendekatan studi kasus. Penelitian ini menggunakan wawancara yang dilaksanakan secara mendalam kepada setiap informan. Hasil penelitian ini menunjukkan bahwa tahap pelaksanaan Dana Desa di Desa Umbulsari sudah melaksanakan penerapan prinsip partisipasi dan transparansi. Untuk tahap pelaksanaan dana desa sudah melaksanakan penerapan prinsip partisipasi, transparansi serta akuntabilitas. Sedangkan pada tahap pertanggungjawaban dana desa sudah melaksanakan penerapan prinsip akuntabilitas.
\end{abstract}




\section{PENDAHULUAN}

Pada sistem pemerintahan, negara mempunyai peran strategis sebagai elemen kesatuan Republik Indonesia, terutama pemerintah desa dari pemerintah daerah terutama Kabupaten/Kota untuk melaksanakan proses pembangunan. Semuanya dilaksanakan sebagai langkah pemerintah pusat untuk memberikan dukungan terhadap pelaksanaan otonomi daerah. Pemerintah desa adalah strata pemerintahan paling bawah yang berkaitan secara langsung terhadap masyarakat. Sehingga tingkat kepercayaan masyarakat terhadap pengelolaan pemerintah desa adalah perihal yang benar-benar penting serta diperlukan. Berhubungan terhadap hal itu, diatur dalam Peraturan Menteri (Permen) No 113 Tahun 2014 menjelaskan bahwa "Desa ialah desa dan desa adat atau yang disebut dengan nama lain, berikutnya disebut Desa, ialah kesatuan masyarakat hukum yang mempunyai batas wilayah yang berwenang guna mengatur maupun mengurus urusan pemerintahan, kepentingan masyarakat setempat berlandaskan masyarakat, hak asal usul, dan/atau hak tradisional yang diakui serta dihormati pada sistem pemerintahan NKRI."

Guna mewujudkan desa yang maju, mandiri serta demokratis, memerlukan anggaran untuk pembangunan maupun pemberdayaan warga pada sebuah desa. Anggaran itu dilakukan pengaturan dalam Peraturan Pemerintah No. 43 Tahun 2014 Pasal 1 angka 8 menyatakan "Dana Desa ialah dana yang bersumber dari APBN (Anggaran Pendapatan Belanja Negara) yang diperuntukkan untuk desa, ditransfer lewat APBD (Anggaran Pendapatan Belanja Daerah) Kabupaten/Kota guna membiayai pelaksanaan pemerintahan, penyelenggaraan pembangunan, pembinaan kemasyarakatan serta pemberdayaan masyarakat". Pemerintah Daerah mempunyai kewenangan yang lebih luas dalam pengelolaan daerahnya. Salah satu bentuk kepedulian pemerintah terhadap pengembangan wilayah pedesaan adalah dengan dialokasikannya Dana Desa dalam bentuk Alokasi Dana Desa (ADD) oleh pemerintah. Inilah yang kemudian melahirkan suatu proses baru tentang desentralisasi desa, diawali dengan digulirkannya Alokasi Dana Desa (ADD).

Alokasi Dana Desa (ADD) sebagaimana dimaksud pada Undang-Undang No.6 Tahun 2014 Pasal 72 ayat (3) paling sedikit 10\% (sepuluh perseratus) dari dana perimbangan yang diterima Pemerintah Kabupaten/Kota. Melihat dari segi kegunaan Dana Desa yang dipergunakan untuk pemberdayaan masyarakat serta pembangunan, sedangkan Alokasi Dana Desa (ADD) digunakan untuk meningkatkan sarana pelayanan masyarakat dengan prinsip hemat dan terarah. Dengan bergulirnya dana-dana tersebut harus menjadikan desa benar-benar sejahtera. Namun memang ini semua masih dalam 
angan-angan. Untuk persoalan Dana Desa (DD) saja, meski telah diwajibkan untuk dianggarakan di pos APBD, namun lebih banyak daerah yang belum melakukannya. Untuk itu, seharusnya proses transformasi yang mengarah terhadap pemberdayaan desa harus terus dilaksanakan dan didorong oleh semua elemen untuk menuju Otonomi Desa.

Daerah atau Desa pada saat menjalankan hak, kewenangan maupun kewajibannya untuk melakukan pengelolaan terhadap kemampuan maupun potensi yang dipunya dituntut untuk dilakukan secara transparan, partispatif serta mempunyai akuntabilitas yang tinggi. Selain itu akuntabilitas adalah adalah upaya negara dalam perihal ini yakni pemerintah dalam menciptakan pelaksanaan pemerintahan ke arah yang semakin baik melalui berdasarkan good governance.

Good governance (Retno Murni Sari, 2015) ialah pelaksanaan pemerintahan negara yang kuat maupun bertanggung jawab dan efisien serta efektif dengan tetap menjaga keseimbangan sinergitas konstruktif diantara domain negara, sektor swasta serta masyarakat. Akuntabilitas diharapkan bisa memperbaiki kualitas maupun kinerja dari instansi kepemerintahan supaya menjadi pemerintahan yang transparan serta mempunyai orientasi kepada kepentingan publik. Adapun konsep dari akuntabilitas dilandaskan kepada sejumlah individu ataupun kelompok jabatan pada setiap klasifikasi jabatan bertanggung jawab kepada kegiatan yang dilaksanakannya. Akuntabilitas pada pemerintahan desa dapat mengikutsertakan kemampuan pemerintah desa guna mempertanggungjawabkan kegiatan yang diselenggarakan yang berkaitan terhadap permaasalahan pembangunan maupun Pemerintahan Desa.

Pertanggungjawaban yang dimaksud berkaitan terhadap permasalahan finansial yang ada pada Anggaran Pendapatan Belanja Desa (APBDes) dan Dana Desa selaku salah satu komponen didalamnya. Fungsi akuntabilitas dapat berperan lebih luas lagi, bukan cuma hanya ketaatan terhadap aturan perundangan yang berlaku. Namun fungsi akuntabilitas selalu memperhatikan pemakaian sumber daya dengan cara bijaksana, efisien, efektif serta ekonomis. Pelaksanaan pemerintahan ataupun pelaksanaan perusahaan wajib menitikberatkan tujuan utama dari akuntabilitas, supaya tiap pengelola bisa menyampaikan akuntabilitas keuangan melalui pembuatan laporan keuangan. Pada umumnya, fenomena yang terjadi di desa, banyak sekali lokasi-lokasi atau tempat-tempat yang digunakan sebagai akses masyarakat masih tidak diperbaiki oleh pemerintah desa setempat. DD yang semestinya disalurkan untuk pembangunan dan pemberdayaan masyarakat tidak dipergunakan sesuai atas peraturan yang ada.

Maka sebab itu, perlu dilaksanakan pengembangan wilayah desa dengan mengimplementasikan DD terhadap pembangunan dan pemberdayaan masyarakat. Pemilihan objek penelitian ini dilaksanakan di Desa Umbulsari Kabupaten Jember dilandaskan kepada fenomena yang terjadi di Desa tersebut. Di Desa Umbulsari dalam pengelolaan DD yang diimplementasikan dalam bentuk pembangunan dan 
pemberdayaan masyarakat dari tahun 2019-2020 terjadi peningkatan dengan baik dibandingkan dengan Desa sekitar. Hal tersebut dapat dibuktikan dengan adanya transparansi anggaran pembangunan yang selalu dipublikasikan secara sederhana yaitu melalui banner yang terletak di depan kantor Desa Umbulsari, sedangkan di desa sekitar dalam satu Kecamatan tidak melakukan publikasi transparansi pembangunan, karena di desa tersebut belum ada pertanggungjawaban yang dapat diaudit oleh pihak berwenang. Sehingga hal tersebut dapat menjadi pilot project implementasi dari akuntabilitas bagi desa lainnya.

Maka sebab itu, peneliti tertarik untuk melaksanakan penelitian terkait Sistem Akuntabilitas Pengelolaan DD di Desa Umbulsari dengan menitikberatka kepada implementasi prinsip akuntabilitas yang dilaksanakan dari tim pelaksana yang dibentuk tiap-tiap desa, karena peneliti juga ingin mengetahui apakah hal tersebut dapat menjamin akuntabilitas pengelolaan DD. Akuntabilitas dipakai selaku media yang bisa membuktikan serta menerangkan sejumlah rencana strategis maupun tujuan yang sudah dilakukan perencanaan serta dilakukan penetapan oleh organisasi pemerintahan bisa berjalan sesuai atas tujuan awal dengan efisen serta efektif. Akuntabilitas pada sistem pengelolaan dana pemerintahan desa ditujukan pula selaku upaya guna menciptakan tata kelola pemerintahan yang baik. Prinsip akuntabilitas menetapkan bahwa tiap kegitan maupun hasil akhir dari kegiatan penyelenggaraan itu haruslah bisa dipertanggungjawabkan terhadap rakyat ataupun masyarakat selaku pemegang kedaulatan paling tinggi negara yang sesuai terhadap ketetapan aturan perundangundangan yang berlaku.

Penerapan prinsip akuntabilitas pengelolaan Dana Desa (DD) diawali dari tahapan perencanaan, penyelenggaraan seluruh kegiatan serta sesudah kegiatan pengelolaan DD diharapkan bisa dipertanggungjawabkan. Beberapa prinsip akuntabilitas dalam instansi kepemerintahan haruslah terdapat komitmen pimpinan serta seua staf guna menjalankan pengelolaan penyelenggaraan supaya transpran, partisipatif dan akuntabel, harus merupakan sistem yang memberikan jaminan terhadap pemakaian sumber daya secara konsisten terhadap atauran perundang-undangan yang berlaku, harus memperlihatkan tingkat pencapaian tujuan serta sasaran yang sudah dilakukan penetapan, sebagai perubahan manajemen instansi kepemerintahan dengan wujud penyusunan laporan yang akuntabel. Sejumlah penelitian terdahulu telah mengamati terkait Akuntabilitas Pengelolaan Dana Desa. Penelitian dari Astri Juainita Makalalag, Grace B Nangoi dan Herman Karamoy (2017), dalam penelitian tersebut memperlihatkan bahwasannya akuntabilitas pengelolaan DD di Kecamatan Kotamobagu Selatan Kota Kotamobagu 
sudah dijalankan berlandaskan atas prinsip transparan, partisipatif serta akuntabel.

Pada pelaporan maupun pertanggungjawaban telah dijalankan sesuai terhadap mekanisme berlandaskan atas ketetapan meskipun masih ada kelalaian dari aparatur desa serta pengelola teknis kegiatan. Sedangkan pada penelitian Boedijono, Galih Wicaksono, Yeni Puspita, Sandhika Cipta Bidhari, Nurcahyaning Dwi Kusumaningrum dan Venantya Asmandani (2019), hasil yang diperoleh dari penelitiannya yakni secara umum desa yang ada di Kabupaten Bondowoso sudah melaksanakan keuangan desa dengan baik, akan tetapi dalam perihal tertentu masih belum tertib dalam hal administrasi, sehingga terkadang mengalami keterlambatan untuk pencairan keuangan desa guna periode berikutnya.

Dalam penelitian Nurul Hidayah, Iin Wijayanti (2017), Hasil penelitiannya memperlihatkan bahwa tahapan perencanaan Dana Desa dalam pemerintahan Desa Wonodadi surah mengimplementasikan prinsip partisipasi. Pada tahapan pelaksanaan Dana Desa, pemerintahan Desa Wonodadi belum menjalankan prinip transparansi dikarenakan pemerintahan desa belum bersedia memberi informasi ataupun data terkait keuangan Desa. Hasil dari penelitian sebelumnya yang sudah dijabarkan tersebut, maka peneliti tertarik untuk meneliti terkait Akuntabilitas Pengelolaan Dana Desa dengan jenis penelitian kualitatif dengan studi kasus.

\section{METODE PENELITIAN}

\section{Pendekatan dan Strategi Penelitian}

Penelitian ini memakai metode kualitatif yang memiliki sifat eksploratif melalui pendekatan studi kasus. Penelitian ini ialah penelitian terhadap masalah empiris dengan menggali dengan luas terkait sebab-sebab yang memberikan pengaruh terhadap berlangsungnya suatu masalah. Penelitian ini bermaksud guna menerangkan serta mengkaji secara rinci Akuntabilitas Pengelolaan Dana Desa di Desa Umbulsari. Hasil dari investigasi tersebut ialah pemaparan kasus yang rinci, intensif serta menyeluruh.

\section{Teknik Pengambilan Sampel}

Teknik pengambilan sampel dalam penelitian ini memakai teknik snowball sampling. Teknik ini dipakai untuk memberi label atau kode pada saat peneliti mengumpulkan data dari responden satu ke responden lain karena penelitian ini memakai wawancara yang dilaksanakan dengan mendalam kepada setiap informan. Pada penetapan sampel, langkah pertama yakni dilakukan pemilihan satu ataupun dua orang, namun dikarenakan dua orang tersebut belum dapat dirasa lengkap atas data yang diberikan, maka peneliti mencari orang lain yang dinilai lebih tahu dan bisa melengkapi data yang diberikan dari dua orang sebelumnya. Begitupun selanjutnya, sehingga jumlah sampel semakin banyak.

\section{Metode Pengambilan Data}
a. Observasi 
Observasi sistematis yang dilakukan antara lain dengan penyusuran desa dengan didampingi tokoh masyarakat desa tersebut.

b. Studi Pustaka

Peninjauan ulang kembali sebagai bentuk klarifikasi kepada pihak terkait untuk mengetahui kebenaran tulisan tersebut.

c. Wawancara

Guna menghimpun data maupun informasi yang akurat serta valid, peneliti melaksanakan wawancara dengan mendalam, dibantu menggunakan alat perekam. Alat perekam tersebut bermanfaat untuk bahan crosscheck, apabila ketika analisis ada data ataupun informasi yang tidak sempat dilakukan pencatatan oleh pewawancara.

\section{Pendekatan dalam Analisis Data}

Penelitian ini memakai pendekatan studi kasus dengan analisis tematik. Pada analisis ini peneliti akan menganalisis secara mendalam dengan mendeskripsikan dan mengakaji, kemudian menginterpretasikan dengan menggunakan metode MDAP (Manual Data Analysis Procedure) atas apa yang disampaikan oleh responden penelitian. Bisa dideskripsikan seperti di bawah ini.

1. Reduksi Data

Data yang telah didapatkan kemudian oleh peneliti dikelompokkan, dipilah-pilah dan sortir yang tidak perlu hingga kemudian dapat ditarik dan diverifikasi. Proses reduksi data itu berjalan secara terus-menerus sepanjang penelitian berlangsung.

\section{Penyajian Data}

Data dilakukan pemilahan maupun disihkan supaya dilakukan penyortiran berdasarkan kelompoknya serta disusunn berdasarkan kategori sejenis untuk disajikan supaya selaras terhadap masalah yang dikaji, termasuk kesimpulan sementara yang didapatkan ketika data dilakukan reduksi.

\section{Penarikan Kesimpulan/Verifikasi}

Selama pengumpulan data peneliti selalu melakukan kegiatan reduksi data, penyajian data maupun pengambilan kesimpulan ataupun verifikasi. Disamping itu, juga melakukan pengkodean data, mengarah pada gagasan baru guna dimasukkan kedalam penyajian data. Pencatatan data mensyaratkan reduksi data berikutnya, begitu penyajian data terisi, kesimpulan dan verivikasi awal bisa ditarik, sampai didapat kesimpulan yang benar. 


\section{HASIL PENELITIAN \\ Orientasi Kancah Penelitian}

1. Geografi dan Topografi Desa Umbulsari

Lokasi Desa Umbulsari berada di Kecamatan Umbulsari, Kabupaten Jember, Provinsi Jawa Timur, Indonesia. Desa Umbulsari terletak tidak jauh dari jalan raya, sehingga Desa Umbulsari sendiri tidak tergolong desa yang sepi. Desa Umbulsari sendiripun sudah terbilang sedikit maju, hal ini dikarenakan Desa Umbulsari dikelilingi petani modern. Jarak ke Kecamatan: 1,1/2 km², Jarak ke Kabupaten : $49 \mathrm{~km}^{2}$, Jarak ke Provinsi : $181 \mathrm{~km}^{2}$. Luas Desa Umbulsari sekitar kurang dari $571.000 \mathrm{~km}^{2}$. Dan desa ini terdiri dari dua dusun yakni Dusun Krajan serta Dusun Sumberejo, 25 RW dan 50 RT.

2. Demografi Desa Umbulsari

Jumlah penduduk Desa Umbulsari secara keseluruhannya kurang lebih 7855 jiwa. Jumlah berdasarkan jenis kelamin untuk perempuan sekitar 4034 dari jumlah keseluruhan dan begitupun jumlah untuk laki-laki sekitar 3821 dari jumlah keseluruhan. Organisasi di Desa Umbulsari cukup banyak, hal ini kemungkinan besar di sebabkan oleh desa yang cukup maju. Beberapa organisasi di desa ini yaitu BPD, LPMD, PKK, Karang Taruna, Karang Werda, BUMDES, SATLINMAS serta BHABINKAMTIBMAS.

3. Prasarana dan Sarana Insfrastruktur Desa Umbulsari

Prasana yang ada di Desa Umbulsari meliputi jaringan listrik, jalan, dan jaringan telekomunikasi. Prasarana tersebut sudah dapat dinikmati oleh masyarakat Desa Umbulsari dengan baik. Semua rumah warga sudah teraliri aliran listrik dari PLN, kondisi jalannya sudah cukup baik yang mana sepanjang jalan jalur kedesa dan jalan yang masuk di area pemukiman warga sudah teraspal. Selain prasarana juga terdapat sarana infrastruktur meliputi sarana peribadahan, sarana kesehatan serta pendidikan. Desa Umbulsari ini bukan termasuk desa yang tidak maju lagi namun desa ini sudah dikategorikan maju.

\section{Pelaksanaan Penelitian}

Penelitian ini dilaksanakan peneliti sekitar 3 bulan, yang berawal dari 1 Januari sampai 30 Maret 2021. Jumlah informan yakni enam orang. Pelaksanaan penelitian dilakukan dengan wawancara dari Kepala Desa sampai ke tokoh masyarakat. Wawancara ini dilakukan untuk menjawab dari tujuan penelitian ini. Pihak pemerintah desa maupun masyarakat sangat mengapresiasi dalam pelaksanaan wawancara tersebut.

\section{PEMBAHASAN}

\section{Perencanaan Pengelolaan Dana Desa}

Berdasarkan Peraturan Menteri Keuangan Republik Indonesia No. 205 /PMK.07/2019 terkait Pengelolaan Dana Desa, Dana Desa ialah dana yang sumbernya dari APBN yang diperuntukkan bagi Desa yang ditransfer lewat APBD Kabupaten 
ataupun Kota serta dipakai guna membiayai pelaksanaan pemerintahan, penyelenggaraan pembangunan, pembinaan kemasyarakatan serta pemberdayaan masyarakat. Dana Desa menjadi salah satu pendapatan desa yang pemakaiannya terintegrasi terhadap APBDes, maka sebab itu program perecanaan maupun kegiatannya dilakukan penyusunan lewat Musyawarah Perencanaan Desa. Musyawarah Perencanaan Desa ialah forum musyawarah yang mengkaji sejumlah usulan perencanaan ataupun program pembangunan desa yang berdasar kepada beberapa prinsip Perencanaan Pembangunan Masyarakat Desa atau disingkat menjadi P3MD.

Prinsip itu mewajibkan partisipasi warga pada pengambilan keputusan serta menetapkan pembangunan yang hendak dijalankan terutama yang berlokasi di desa bersangkutan. V. Wiratna (2015:29) Partisipasi ialah prinsip yang mana bahwa tiap masyarakat desa di desa yang bersangkutan memiliki hak agar berpartisipasi pad tiap pengambilan keputusan dalam tiap kegiatan yang dilaksanakan dari pemeintahan desa dimana mereka tinggal. Partisipasi warga pada pengambilan keputusan itu bisa dengan cara langsung maupun tidak langsung. Penerapan program DD di Desa Umbulsari Kabupaten Jember dijalankan pula untuk rangka pemberdayaan masyarakat serta menitikberatkan kepada proses motivasi berpartisipasi untuk pembangunan desa. Hal itu sesuai dengan informasi sebagai berikut :

"Jadi gini prosesnya ya. Yang pertama, kasi perencanaan itu beserta....apa namanya pembuat RAB nah itu membuat RAB terus kasi perencanaan itu menyusun, titik-titik mana yang mau dibangun yang menjadi prioritas, itu yang pertama ya. Setelah itu, jadi kita tampung aspirasi semua warga, di tampung.. jalan titik A RW berapa gitu kan. Ada warga yang mengadu kita sikapi kemudian kita crosschek dilapangan. Ohh ini.. sek gampangane ee.. ndak harus sekarang. Jadi kita survey dilapangan yang menjadi skala prioritas, setelah itu kita musdeskan, ya masyarakat, BPD, LPM, terus tokoh-tokoh masyarakat itu kita hadirkan dengan musyawarah desa. Musyawarah desa dulu. Jadi tahapannya itu musdes dulu, setelah musdes di musrenbangdeskan, itu penetapan sudah. Jadi di musdes itu mana yang menjadi skala prioritas baru musrenbangdes." (Hasil wawancara dengan DK)

Semua kegiatan yang bersumber dari DD ialah program yang menjadi kebutuhan warga serta menjadi prioritas agar dijalankan guna terwujudnya efektivitas pemakaian dana yang sudah ditetapkan dari Pemerintah Daerah. Hasil dari perencanaan anggaran maupun program yang sudah dilakukan pengesahan dengan peraturan desa akan menjadi pedoman pelaksanaan pemerintahan desa serta pembangunan pada masa 1 tahun anggaran terhitung sejak 1 Januari hingga 31 Desember tahun berkenaan. Maka 
sebab itu, perencanaan yang disepakati haruslah transparan, bisa diketahui oleh semua warga yang nantinya bisa dipertanggungjawabkan.

Guna melaksanakan penerapan prinsip transparansi, pemerintah desa wajib memberi informasi pada masyarakat terkait program yang akan diselenggarakan. Dengan melaksanakan hal tersebut, pemerintah desa sudah berupaya untuk mengimplementasikan prinsip transparansi serta akuntabilitas. Hal tersebut sesuai dengan informasi seperti berikut :

"Kita selalu ada. Sebelum eee... proyek dilaksanakan kita ada papan informasi, ada papan nama proyek eee... mesti ditancapkan disitu sebelum proyek dijalankan. Jadi masyarakat tau disini mau... misalkan dibangun proyek pavingisasi, eee... berapa meter terus eee... anggaran biayanya berapa itu ada semua." (Hasil wawancara dengan KP)

Pernyataan tersebut memperlihatkan bahwa prinsip partisipasi warga cukup baik yang diikuti pula melalui prinsip transparansi dalam perencanaan pengelolaan DD. Penelitian ini mendukung penelitian sebelumnya yaitu penelitian Nurul Hidayah, Iin Wijayanti (2017), yang mengemukakan bahwa tahapan perencanaan pengelolaan Dana Desa sudah mengimplementasikan prinsip partisipasi.

\section{Pelaksanaan Pengeloaan DD}

Program yang didanai oleh DD, secara penuh dijalankan oleh Tim Pelaksana Desa. Pada penyelenggaraan program DD tersebut, diperlukan keterbukaan dari Tim Pelaksana Desa pada semua lapisan masyarakat. Salah satu bentuk nyata untuk mendukung keterbukaan informasi program DD ialah melalui melakukan pemasangan papan informasi yang berisi jadwal penyelenggaraan kegiatan fisik yang sedang dijalankan. Keterbukaan informasi tersebut adalah upaya pemerintahan desa guna menjalankan prinsip transparansi pada perihal pengelolaan DD. Hal tersebut sesuai dengan informasi sebagai berikut :

"Jadi, itu sebagai apa namanya sebuah kewajiban juga. Jadi sebelum dibagun satu minggu atau 15 hari sebelum dibangun itu sudah dikasih papan, papan dari sumber dana apa misal sumberdana DD, volume, lebar, panjang itu diterangkan di papan itu, setelah itu, eee nilainya berapa itu. Dan setelah dibangun ada prasasti itu. Jadi, ada papan juga ada prasasti gitu." (Hasil wawancara dengan DK)

Pendapat informan tersebut menunjukkan bahwa prinsip transparansi sudah dilaksanakan oleh Pemerintah Desa Umbulsari. Melalui terdapatnya informasi yang jelas terkait program yang dilaksanakan dalam pengelolaan DD, masyarakat bisa mengetahui dengan jelas serta hal tersebut dapat mendorong terselenggarakannya prinsip partisipasi. Dalam mewujudkan prinsip partisipasi dalam pelaksanaan program yang didanai oleh DD pada perihal ini, pemerintah desa melibatkan langsung warga desa pada pembangunan yang sedang dilaksanakan. Warga desa diberdayakan untuk menjadi tenaga kerja di wilayahnya. Hal ini sesuai dengan informasi sebagai berikut : 
"LPMD di Desa Umbulsari melaksanakan apa yang sudah diwenangkan oleh bapak Kepala Desa dan bapak Kepala Desa memang mewanti-wanti, kami sendiri juga memahami mempelajari masalah penggunaan anggaran DD itu khusunya yaitu, dengan penerapan sebaik-baiknya, mutu yang terbaik terus tenaga kerja ahli, mungkin paving punya ahli, kita bisa eee... istilahnya mencari 1 atau 2 instruktur untuk mempelajari temen-temen yang diwilayah setempat, yang utama lagi itu pemberdayaan, pemberdayaan masyaraakat khusus wilayah yang kita eeee... yang dibangun tadi. Kalau wilayah ee..yang kami sebut tadi misalkan dusun B berarti kita menggunakan eee...masyarakat setempat untuk pemberdayaan lingkungan disitu khususnya dilingkungan dimana infrastruktur itu kita bangun." (Hasil wawancara dengan KL Desa Umbulsari)

Berdasarkan sisi prinsip akuntabilitas penyelenggaraan pengelolaan DD dapat diwujudkan lewat sistem pelaporan yakni pelaporan bulanan serta laporan tiap-tiap kegiatan. Hal itu sesuai dengan informasi sebagai berikut :

"Jadi di akhir tahun kita disamping realisasi kita juga ada LPJ (Laporan Pertanggungjawaban) pasti itu, dan itu disetiap ee anggaran desa itu turun 3 tahap jadi sebelum kita ee melaksanakan menyerahkan LPJ itu dimonitoring oleh pihak PU Kecamatan dan setelah itu di akhir tahun kita eee kemarin juga dimonitoring oleh kejaksaan kaitannya dengan LPJ selalu begitu." (Hasil wawancara dengan DK)

Peryataan dari para informan tersebut memperlihatkan bahwa prinsip partisipasi sudah dilaksanakan dengan baik yang diikuti pula atas penerapan prinsip transparansi. Pada penyelenggaraan DD selalu dilaksanakan pelaporan perkembangan penyelenggaraan kegiatan oleh pengelola DD di tingkat desa. Oleh karena itu, bisa diketahui bahwa tanggung jawab pengelola DD di tingkat desa telah memenuhi ketetapan pembuatan laporan kegiatan DD yang bertahap serta laporan akhir kegiatan. Pada tahapan penyelenggaraan pengelolaan DD, pemerintah desa dan masyarakat sudah melaksanakan penerapan prinsip transparansi, partisipatif serta akuntabilitas sesuai dengan Permendagri No. 113 Tahun 2014 tentang Pengelolaan Keuangan Desa. Penelitian ini bertolak belakang dengan penelitian Khalida Shuha (2018), yang mengemukakan bahwa pada tahap pelaksanaan tidak sesuai dengan Permendagri No. 113 Tahun 2014.

\section{Pertanggungjawaban Pengeloaan DD}

Berdasarkan atas Peraturan Menteri Keuangan Republik Indonesia No. 205 /PMK.07/2019 BAB VI Tentang Penatausahaan, Pertanggungjawaban serta Pelaporan menyebutkan bahwa : 
Pasal 29:

(1) "Dalam rangka pertanggungjawaban penyaluran Dana Desa, KPA Penyaluran DAK Fisik dan Dana Desa menyampaikan laporan sebagaimana dimaksud dalam Pasal 3 ayat (7) huruf d kepada Koordinator KPA Penyaluran DAK Fisik dan Dana Desa paling lambat tanggal 10 (sepuluh) bulan berikutnya.

(2) Koordinator KPA Penyaluran DAK Fisik dan Dana Desa sebagaimana dimaksud pada ayat (1) menyampaikan konsolidasi laporan sebagaimana dimaksud dalam Pasal 3 ayat (10) huruf a dan huruf b kepada Direktur Jenderal Perimbangan Keuangan setiap bulan paling lambat tanggal 15 (lima belas) bulan berikutnya."

Dengan begitu bbisa diambil kesimpulan bahwa semua kegiatan yang didanai oleh DD harus di pertanggungjawabkan setiap kegiatannya maupun setiap tahun berkenaan, sehingga pertanggungjawabannya dapat dilaporkan dengan memenuhi prinsip akuntabel dan transparan. Hal tersebut dapat dibuktikan dengan informasi sebagai berikut :

"Kalau LPJ itu dari monitoring khususnya selama ini selama ini tidak ada halangan. Sekali mungkin kalau revisi mungkin 1 sudah wajar begitu. Nyatanya selama ini saya tidak pernah dengar dan saya yang saya ikuti untuk LPJnya tidak ada kendala lancarlancar aja. Karena apa dari penilaian awal monitoring hasil pembangunan tadi ya itu tidak ada kendala. Bahkan dari setiap monitoring itu, apa istilahnya ya, ya seperti ini Desa Umbulsari ini ya selalu sebagai percontohan dari desa-desa yang lainnya katanya seperti itu Ini saya tidak bohong lo, ini asli dari pihak monitoring di buat percontohan melangkah mulai dari awal jadi laporan pertanggungjawabannnya juga tidak ada masalah.” (Hasil wawancara dengan KL Desa Umbulsari)

Berdasarkan sisi prinsip transparansi pelaksanaan DD dapat dilihat dari penyampaian informasi keuangan yang terbuka maupun jujur pada masyarakat berlandaskan pertimbangan bahwa masyarakat mempunyai hak guna mengetahui dengan terbuka serta menyeluruh terhadap pertanggungjawaban pemerintah desa pada pengelolaan DD. Hal tersebut dapat dibuktikan dengan informasi sebagai berikut :

"Njenengan lihat itu banner di depan (sambil menunjuk banner di depan kantor desa) semuanya transparansi. Jadi masyarakat bisa melihat, Kalau memang ada perubahan maka akan ada banner disitu di informasikan kita buatkan anu APBDes perubahan tertulis transparansi APBD. Itu seperti didepan itu ya (sambil menunjuk banner di depan kantor desa). Jadi semua tau kalau memang ada perubahan." (Hasil wawancara dengan KSK)

Berdasarkan informasi yang diberikan dari para informan di atas menunjukkan bahwa pertanggungjawaban pengelolaan DD sudah dilaksanakan dengan memenuhi prinsip akuntabel dan transparan. Penelitian ini mendukung penelitian sebelumnya yaitu penelitian Nunuk Riyani (2016), yang menyatakan bahwa Analisis Dana Desa di Desa Singopuran telah tersampaikan untuk pembangunan secara baik sesuai atas perencanaan 
akan tetapi masih terdapat evaluasi yang harus diperbaiki.

\section{Akuntabilitas Sistem Pengelolaan Dana Desa (DD)}

Akuntabilittas pengelolaan DD sangat dibutuhkan guna mewujudkan good governance ataupun tata kelola pemerintahan yang baik. Pemerintah desa serta otonomi tidak akan mempunyai makna serta memiliki manfaat untuk warga desa apabila tidak ditunjang melalui transparansi, partisipasi dan akuntabilitas. Berlandaskan prinsip itu, maka akuntabilitas pengelolaan DD di Desa Umbulsari telah semestinya difokuskan pada tahapan perencanaan, pelaksanaan dan pertanggungjawaban. Akuntabilitas pengelolaan DD diawali dari tahap perencanaan, pelaksanaan serta pertanggungjawaban.

Berdasarkan atas prinsip umum pengelolaan keuangan desa memuat tiga aspek yaitu asas transparan, partisipatif serta akuntabel, maka pengelolaan DD harus dijalankan dengan cara terbuka melalui musyawarah desa, kemudian dimusrengbangdeskan serta hasilnya dimuat pada Peraturan Desa. Hal itu memperlihatkan bahwa pengelolaan DD dilaksanakan secara transparan, akuntabel dan partisipatif. Ketentuan tersebut juga sesuai dengan prinsip good governance pada pengelolaan DD.

Penerapan sejumlah prinsip itu dapat diketahui dari tahapan perencanaan, pelaksanaan serta pertanggungjawaban. Dari hasil penelitian dia atas dapat dirangkum bahwa Sistem Akuntabilitas Pengelolaan Dana Desa di Desa Umbulsari sudah mengimplementasikan prinsip akuntabilitas. Penelitian ini mendukung penelitian sebelumnya yaitu penelitian Astri Juainita Makalalag, Grace B Nangoi dan Herman (2017), menyebutkan bahwa akuntabilitas pengelolaan dana desa di Kecamatan Kotamobagu Selatan sudah dijalankan berlandaskan atas prinsip transparan, partisipatif serta akuntabel.

\section{PENUTUP}

\section{Kesimpulan}

Akuntabilitas Pengelolaan Dana Desa di Desa Umbulsari Kabupaten Jember, bisa ditarik kesimpulan seperti berikut :

1. Tahapan perencanaan Dana Desa di Desa Umbulsari telah melaksanakan penerapan prinsip partisipasi dan transparansi. Hal tersebut dibuktikan melalui adanya musyawarah desa, pemerintah desa terbuka untuk menerima semua usulan masyarakat dan menjadikan suara masyarakat sebagai keputusan tertinggi dalam musyawarah desa agar berlangsungnya pembangunan di desa tersebut. 
2. Tahapan pelaksanaan Dana Desa di Desa Umbulsari telah melaksanakan penerapan prinsip partisipasi, transparansi serta akuntabilitas. Hal tersebut dibuktikan dengan adanya partisipasi masyarakat dalam bentuk pemberdayaan masyarakat untuk pelaksanaan pembangunan di desa tersebut. Sementara itu, untuk prinsip transparansi dibuktikan melalui terdapatnya informasi yang jelas terkait jadwal penyelenggaraan program yang dibiayai dari DD. Untuk prinsip akuntabilitas sudah terlaksana seutuhnya dikarenakan pertanggungjawabannya telah sesuai dengan aturan yang berlaku.

3. Tahap pertanggungjawaban Dana Desa di Desa Umbulsari sudah melaksanakan penerapan prinsip akuntabilitas. Hal tersebut bisa dibuktikan dengan adanya pelaporan dan pertanggungjawaban yang dilaporkan sesuai dengan aturan yang berlaku pada setiap kegiatan dan tahun berkenaan.

\section{Implikasi}

Berlandaskan dari hasil penelitian yang sudah dilaksanakan, maka implikasi dari penelitian ini ialah pemerintah desa dalam melaksanakan program yang didanai oleh Dana Desa harus melaksanakan penerapan prinsip transparansi, partisipasi masyarakat serta akuntabilitas. Prinsip tersebut dapat diterapkan dalam perencanaan kegiatan, pelaksanaan dan pertanggungjawaban. Sehingga pengelolaan Dana Desa bisa diselenggarakan dan dipertanggungjawabkan sesuai atas aturan yang berlaku. Kegiatan yang sudah diselenggarakan dapat dipertanggungjawabkan dan dapat diaudit oleh pihak eksternal, sehingga dapat dievaluasi untuk program selanjutnya.

Sesuai dengan penelitian terdahulu, Gayatri, Made Yeni Latrini, Ni Luh Sari Widhiyani (2014), bahwa hubungan diantara penerapan tranparansi serta akuntabilitas terhadap pengelolaan keuangan dana desa serta hubungan diantara variabel itu ialah kuat. Sehingga semakin baik transparansi, partisipasi dan akuntabilitas, maka pengelolaan Dana Desa dapat dilaksanakan sesuai perencanaan yang sudah ditetapkan. Apabila ketiga prinsip tersebut tidak dilakukan pada penyelenggaraan pengelolaan dana desa, maka pemerintah desa akan menyalahi aturan yang berlaku.

\section{Saran}

Bersumber dari hasil penelitian serta kesimpulan tersebut, adapun saran yang disampaikan guna tercapainya kesempurnaan pada penelitian selanjutnya yaitu seperti di bawah ini.

\section{Saran Teoritis}

a. Untuk penelitian berikutnya diharapkan agar mencari beberapa faktor lainnya yang dapat memepengaruhi akuntabilitas pengelolaan DD. Hal ini dikarenakan penelitian ini hanya pada prinsip transparansi, partisipasi dan akuntabilitas. hal ini penting, karena dapat diketahui perbedaan dengan penelitian yang sejenis selanjutnya. 
b. Wilayah pengambilan responden pada penelitian ini cuma terbatas dalam satu lokasi, sehingga untuk penelitian berikutnya diharapkan bisa membuat lebih luas wilayah penelitiannya unutk hasil yang lebih baik.

2. Saran Praktis

a. Untuk Pemerintah Desa Umbulsari, perlu mempertahankan Sistem Akuntabilitas Pengelolaan Dana Desa sesuai dengan peraturan yang berlaku dan dapat dipertanggungjawabkan.

b. Pemerintah desa dalam merealisasikan anggaran desa harus tetap menerapkan prinsip transparansi, partisipasi dan akuntabilitas. 


\section{DAFTAR PUSTAKA}

Astri Juainita Makalalag, Grace B Nangoi, Herman Karamoy, (2017). Akuntabilitas Pengelolaan Dana Desa di Kecamatan Kotamobagu Selatan Kota Kotamobagu. Jurnal Riset Akuntansi Dan Auditing" Goodwill", 8(1).

Boedijono, Galih Wicaksono, Yeni Puspita, Sandhika Cipta Bidhari, Nurcahyaning Dwi Kusumaningrum, Venantya Asmandani. (2019). Efektifitas Pengelolaan Dana Desa Untuk Pembangunan Dan Pemberdayaan Masyarakat Desa Di Kabupaten Bondowoso. Jurnal Riset Manajemen dan Bisnis (JRMB) Fakultas Ekonomi UNIAT, 4(1), 9 - 20

Ekasari Sugiarti, Ivan Yudianto. (2017),. Analisis Faktor Kompetensi Sumber Daya Manusia, Pemanfaatan Teknologi Informasi, dan Partisipasi Penganggaran Terhadap Akuntabilitas Pengelolaan Dana Desa (Survei Pada Desa-Desa di Wilayah Kecamatan Klari, Kecamatan Karawang Timur, Kecamatan Majalaya dan Kecamatan Rengasdengklok Kabupaten Karawang). Seminar Nasional Akuntansi Dan Bisnis (SNAB), Fakultas Ekonomi Universitas Widyatama..

Gayatri, Made Yeni Latrini, Ni Luh Sari Widhiyani. (2017). Transparansi dan Akuntabilitas Pengelolaan Keuangan Dana Desa untuk Mendorong Kemandirian Masyarakat Pedesaan. Jurnal Ekonomi Kuantitatif Terapan

Khalida Shuha. (2018). Analisis Pengelolaan Dana Desa (Studi Kasus Pada Desa-Desa Selingkungan Kecamatan Lubuk Alung Kabupaten Padang Pariaman). Jurnal Akuntansi, 2018, 6.2.

Mardiasmo. (2009). Akuntansi Sektor Publik. Yogyakarta: Penerbit Andi.

Nanda Widaninggar, Murti Sumarni, Saiful Amin, Nurshadrina Kartika Sari. (2020). Capital Expenditure's Antecedents: Proof Of The Public Sector In East Java. International Journal of Economics, Business and Management Research Vol. 4, No. 03; 2020.

Ni Komang Ayu Julia Praba Dewi, Gayatri (2019). Faktor-Faktor Yang Berpengaruh Pada Akuntabilitas Pengelolaan Dana Desa. E-Jurnal Akuntansi, 26(2), 12691298.

Nunuk Riyani. (2016), Analisis Pengelolaan Dana Desa (Studi Kasus Di Desa Singopran Kecamatan Kartasura Kabupaten Sukoharjo Tahun 2016). Doctoral Dissertation, Universitas Muhammadiyah Surakarta.

Nurul Hidayah, Iin Wijayanti. (2017). Akuntabilitas Pengelolaan Dana Desa (Dd) Studi Kasus Pada Desa Wonodadi Kecamatan Ngrayun Kabupaten Ponorogo. Jurnal AKSI (Akuntansi dan Sistem Informasi) Vol 2 Edisi 1September 2017 p-ISSN : 2528-6145 dan e-ISSN : 2543198.

Peraturan Menteri Keuangan Republik Indonesia Nomor 205 /PMK.07/2019 Tentang Pengelolaan Dana Desa 
Peraturan Menteri Dalam Negeri Nomor 113 tahun 2014 tentang Desa, Pemerintah Desa dan Pengelolaan Keuangan Desa.

Retno Murni Sari. (2015). Akuntabilitas Pengelolaan Anggaran Pendapatan dan Belanja Desa (APBDes) di Desa Bendosari Kecamatan Ngantru Kabupaten Tulungagung. Jurnal Kompilasi Ilmu Ekonomi (KOMPILEK), 7(2), 139-148.

Robert K. Yin. (2013). Studi Kasus Desain dan Metode. Edisi 1. Jakarta: Rajawali Pers. Sherly Gresita Apriliani. (2013). Akuntabilitas Pengelolaan Alokasi Dana Desa Di Desa Kedungrejo Kecamatan Muncar Kabupaten Banyuwangi Tahun 2013. Universitas Jember, Jember, Indonesia.

V. Wiratna Sujarweni. (2015). Akuntansi Desa. Yogyakarta: Pustaka Baru Press.

Yamulia Hulu, R. Hamdani Harahap \& Muhammad Arif Nasution. (2018). Pengelolaan Dana Desa dalam Pemberdayaan Masyarakat Desa. Jurnal Pendidikan Ilmu-Ilmu Sosial, 10(1): 146-154. 